\title{
Pasture-tree systems - Modelling potential implications for animal performance and greenhouse gas emissions
}

\author{
R.E. VIBART ${ }^{1}$, G.B. DOUGLAS ${ }^{1}$, A.D. MACKAY ${ }^{1}$, M.B. DODD ${ }^{1}$, and I.R. McIVOR ${ }^{2}$ \\ ${ }^{1}$ AgResearch, Grasslands Research Centre, Private Bag 11008, Palmerston North \\ ${ }^{2}$ Plant and Food Research, Private Bag 11030, Palmerston North \\ Ronaldo.Vibart@agresearch.co.nz
}

\begin{abstract}
The potential animal performance and greenhouse gas (GHG) abatement benefits from pastures and wide-spaced poplars on a typical lower-North Island sheep and beef farm operation were explored using farm-scale models. The analysis included reductions in understory pasture production, increased ewe reproductive performance (i.e., lambing and weaning percentage) with additional tree shelter and increased dry matter intake from poplar foliage. The pasture-tree systems demonstrated reductions in sheep stocking rates and total meat production, but increases in ewe efficiency and emissions intensity, reflecting a shift in feed energy use from maintenance to production. Inclusion of ewe fecundity and supplementary feed benefits largely overcame reductions in stocking rate and meat production due to pasture shading. An integrated assessment of the multiple benefits of pasture-tree systems should be incorporated in future farming scenario testing, strengthening our knowledge on the impacts of these systems compared with pastureonly systems.
\end{abstract}

Keywords: pasture-tree systems, animal performance, greenhouse gas emissions.

\section{Introduction}

Meat and wool export revenue for New Zealand is forecast to reach $\$ 8.6$ billion in 2015 (Ministry for Primary Industries 2014), and the 4-5 million ha of low altitude hill country in pastoral agriculture are a critical contributor to these earnings. Because of the prominent role ruminant methane emissions play in New Zealand's greenhouse gas (GHG) emissions profile, the pastoral hill country sector is also likely to be a dominant contributor to this environmental issue (Mackay et al. 2012). Wide-spaced planted trees (i.e., pasture-tree or PT), typically poplars and willows, have been historically planted in hill country sheep and beef farm systems for soil conservation purposes (Douglas et al. 2006a; McIvor \& Douglas 2012). In addition to erosion control, spaced trees add to aboveground carbon $(\mathrm{C})$ stocks and provide shelter, shade and supplemental fodder for livestock (Betteridge et al. 2012; McWilliam et al. 2004; Pitta et al. 2005). These effects could mitigate greenhouse gas (GHG) emissions via improved net $\mathrm{C}$ sequestration and reductions in emissions intensity from high-fecundity systems (Mackay et al., 2012). The potential benefits of PT systems for enhanced animal performance and reduced $\mathrm{C}$ emissions to the atmosphere are yet to be quantified. The objective of this paper was to quantify (via modelling) the potential animal performance and GHG abatement benefits from trees planted into a simulated lower North Island sheep and beef farm system, relative to a pasture-only (PO) system without trees.

\section{Materials and Methods \\ Background Information and Modelling Assumptions}

A representative farm system in the Manawatu region in the North Island of New Zealand was created to represent several farming scenarios. The baseline farm (pastures without trees; PO) comprised a hypothetical 368-ha farm located in the Pohangina Valley. This location was chosen due to previous pasture-tree research conducted in the area (Douglas et al. 2006a, b; Guevara-Escobar et al. 2007), which facilitated the inclusion of local soil, climate and pasture growth data into the model. The baseline farm was created by combining the characteristics of a "North Island intensive finishing" system (Class 5; Beef+Lamb New Zealand 2013) and a "Western Lower North Island" (WLNI) system (Ministry for Primary Industries 2012). These two systems are constructed by the sector agencies from regional farm monitoring data as being representative of typical regional farm systems, e.g., the WLNI model represents almost 400 sheep and beef farms located on the west coast of the North Island, south of New Plymouth. Briefly, our modelled baseline farm comprised a sheep breeding enterprise including imported lambs for finishing (an additional $32 \%$ of total lambs weaned on-farm), and a cattle trading enterprise including beef-type bulls, purchased at 3 months of age. All livestock feed was grown on the farm (Table 1).

The land resource for the farm system comprised three blocks with distinct topography: a rolling area (8$15^{\circ}$ slopes; 74 ha; $20 \%$ of the total effective area), an easy hill area (16-25 slopes; 147 ha; $40 \%$ of the total effective area), and a hard hill area ( $>25^{\circ}$ slopes; 147 
ha; $40 \%$ of the total effective area). In the baseline farm system scenario all blocks were pasture-only (PO). To create a pasture-tree (PT) system, the baseline farm was modified to include spaced-trees as follows: within the easy hill area $50 \%$ of the land was in young, widespaced untended poplars (Populus spp.), unevenly spaced (5-20 m apart, 25-400 trees/ha) and aged 8 to 11 years; within the hard hill area, $50 \%$ of the land was in older, mature untended poplars, unevenly spaced (37 trees/ha) and $>25$ years old.

Monthly pasture growth rates for the rolling area were obtained from the Farmax Library (Manawatu "flat"); corresponding PO growth rates for the easy hill area were obtained from Douglas et al. (2006b). Hard hill areas were assumed to produce about $80 \%$ of the pasture grown in the easy hill area (Gillingham 1973). In addition, pasture growth rates under young poplars ( 0.75 of that produced in the PO easy hill) were obtained from Douglas et al. (2006b), whereas the reduction in pasture growth rates under mature, more densely populated poplars ( 0.58 of that produced in the PO hard hill) were obtained from Guevara-Escobar et al. (2007).

\section{Models Used}

The farm system models Farmax ${ }^{\circledR}$ and OVERSEER ${ }^{\circledR}$ were used to construct and examine the performance of the two sheep and beef farming systems described above. In both models a single year "steady state" or "typical year" simulation was conducted. Farmax ${ }^{\circledR}$ Pro (v. 6.5.3.05, www.farmax.co.nz; herein Farmax) was used to construct a biologically feasible system with available feed supply and animal demand, ensuring that pasture covers were maintained within realistic limits. Model outputs included beef, sheep meat and wool production, as well as reproductive performance. The nutrient budget model OVERSEER ${ }^{\circledR}$ (v. 6.2, www. overseer.co.nz; herein Overseer) was used to examine total GHG emissions, including $\mathrm{CO}_{2}, \mathrm{~N}_{2} \mathrm{O}$ and $\mathrm{CH}_{4}$ expressed as $\mathrm{CO}_{2}$-equivalents (Wheeler et al. 2008).

Table 1 Herbage production from pasture, animal characteristics and greenhouse gas (GHG) emissions intensity (kg CO - e/ $/ \mathrm{kg}$ of meat and fibre) of five farm scenarios tested (PO = pasture only; PT0 = Pasture-tree system with no shelter benefits; $\mathrm{PT} 1$ = PT with a 3 percentage point increase in weaning relative to PT0; PT2 = PT with a 10 percentage point increase in weaning relative to PT0; PT+I = PT plus poplar fodder supplementation). Outputs from Farmax.

\begin{tabular}{|c|c|c|c|c|c|}
\hline & \multicolumn{5}{|c|}{ Farming Scenarios } \\
\hline & PO & РT0 & PT1 & PT2 & PT+1 \\
\hline Pasture $^{1}$ & 8794 & 7753 & 7753 & 7753 & 7753 \\
\hline Stocking rate ${ }^{2}$ & 13.4 & 11.8 & 11.9 & 11.8 & 12.1 \\
\hline Ewe numbers & 2379 & 2026 & 2033 & 1985 & 2033 \\
\hline Total sheep numbers & 3402 & 2899 & 2908 & 2841 & 2910 \\
\hline Total cattle numbers & 190 & 190 & 190 & 190 & 190 \\
\hline \multicolumn{6}{|l|}{ Animal dry matter intake, $\mathrm{kg} \mathrm{DM} / \mathrm{ha}$} \\
\hline From pasture & 7316 & 6416 & 6448 & 6428 & 6502 \\
\hline From supplements $^{3}$ & 366 & 366 & 366 & 366 & 447 \\
\hline Total & 7682 & 6782 & 6814 & 6794 & 6949 \\
\hline $\mathrm{FCE}^{4}$ & 24.2 & 24.0 & 23.7 & 23.4 & 22.6 \\
\hline Breeding/sheep DMI, $\%^{5}$ & 75.1 & 75.0 & 74.8 & 74.4 & 73.4 \\
\hline Beef produced, kg/ha & 80 & 80 & 80 & 80 & 80 \\
\hline Sheep meat produced, $\mathrm{kg} / \mathrm{ha}$ & 169 & 144 & 149 & 151 & 167 \\
\hline Wool produced, kg/ha & 55 & 47 & 47 & 47 & 48 \\
\hline Total animal product, $\mathrm{kg} / \mathrm{ha}$ & 304 & 271 & 276 & 278 & 295 \\
\hline Ewe pregnancy, \% & 162 & 162 & 162 & 162 & 165 \\
\hline Ewe lambing, \% & 132 & 132 & 135 & 141 & 144 \\
\hline Ewe weaning, \% & 128 & 128 & 131 & 138 & 141 \\
\hline Ewe efficiency ${ }^{6}, \%$ & 54.7 & 54.7 & 56.0 & 58.7 & 60.0 \\
\hline GHG emissions intensity, $\mathrm{kg} \mathrm{CO}_{2}$-e/kg of meat and fibre & 16.2 & 15.9 & 15.6 & 15.4 & 15.0 \\
\hline
\end{tabular}

${ }^{1}$ Annual herbage growth, $\mathrm{kg} \mathrm{DM} / \mathrm{ha}$.

${ }^{2}$ Stock Units (one $55 \mathrm{~kg}$ ewe and lamb).

${ }^{3}$ From fodder crop grown on-farm, hay from excess pasture growth and poplar fodder (PT+l).

${ }^{4}$ Feed conversion efficiency, $\mathrm{kg}$ DM consumed/kg animal product.

${ }^{5}$ Calculated as the sum of DM intakes (DMI) of breeding ewes, ewe hoggets and rams, expressed as a percentage of total sheep intake.

${ }^{6}$ Total standardised lamb weaning weight (at 90 days, in $\mathrm{kg}$ ) per $\mathrm{kg}$ ewe mated, expressed as a percentage. 


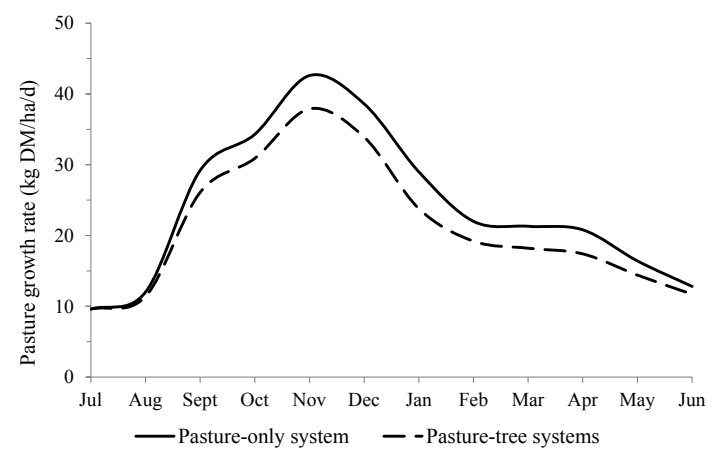

Figure 1 Monthly pasture growth rates (kg DM/ha/day at the end of each month) of the pasture-only and pasture-tree sheep and beef farming scenarios in Manawatu.

Despite the absence of pasture-tree options in the models, pasture yield and animal distribution on PO and PT scenarios was based on the relative pasture yield achieved by each of the land blocks.

\section{Farming Scenarios}

Two farming systems comprising five scenarios were modelled:

- A pasture-only (PO) system with one scenario - no tree effects;

- A pasture-tree (PT) system with four scenarios, as follows:

- Three PT scenarios that accounted for pasture production losses and shelter benefits; these included an option with no benefits from having the trees (PT0), and two options where the shelter benefits represented greater weaning values: a 3 percentage point increase (PT1) or a 10 percentage point increase (PT2) in weaning relative to the PT0 scenario. Impacts on lamb survival are within those reported by Pollard (2006).

- One PT scenario that accounted for pasture production losses, shelter benefits and added dry matter intake (DMI) from poplar fodder $(\mathrm{PT}+\mathrm{I})$; this included the consumption of tree cuttings valued at 11.3 MJME/kg DMI from intact leaves (Douglas et al. 2006a). Except for a slight increase in the number of foetuses per ewe mated due to increased ewe liveweight (McWilliam et al. 2004), the benefits in reduced lamb losses for this scenario were similar to that of PT2. Poplar supplementation occurred over 60 days (early March to late April) including the mating period (starting 15 March), with poplar fodder providing for about $20 \%$ of ewe energy requirements during this period.

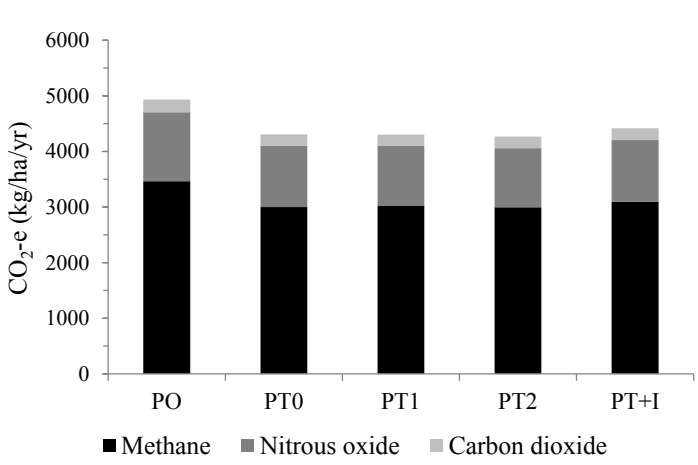

Figure 2 Greenhouse gas emissions (methane, nitrous oxide, carbon dioxide) estimated from Overseer for five farm scenarios tested (PO = pasture only; PTO = Pasture-tree system with no shelter benefits; PT1 $=\mathrm{PT}$ with a 3 percentage point increase in weaning relative to $\mathrm{PTO}$; $\mathrm{PT} 2=\mathrm{PT}$ with a 10 percentage point increase in weaning relative to $\mathrm{PTO} ; \mathrm{PT}+\mathrm{I}=$ PT plus poplar fodder supplementation).

\section{Results}

The shading of pastures by trees led to a reduction in total annual herbage accumulation of approximately $1.0 \mathrm{t} \mathrm{DM} / \mathrm{ha}$ (Figure 1) and a reduction in winter carrying capacity of 1.5 stock units (SU)/ha (Table 1). This reduction was apportioned to the breeding ewe flock numbers. This effect was partially mitigated in $\mathrm{PT}+\mathrm{I}$; the reduction in stocking rate was $1.3 \mathrm{SU} / \mathrm{ha}$ for $\mathrm{PT}+\mathrm{I}$. The shelter benefits from ewes having free access to the tree land blocks (scenarios PT1 and PT2) were captured in reduced lamb losses relative to the PO system, which in turn resulted in greater lambing (135 and $141 \%$ vs. $132 \%$ ) and weaning percentages (131 and $138 \%$ vs. $128 \%$ ) (Table 1). To a greater extent, the additional intake from tree leaves provided for greater reproductive efficiency; lambing percent and weaning percent for $\mathrm{PT}+\mathrm{I}$ were increased to 144 and $141 \%$, respectively.

Feed conversion achieved by the poplar fodder scenario (23.0 kg DMI $/ \mathrm{kg}$ meat + fibre; $\mathrm{M}+\mathrm{F}$ ) was more efficient than that of the PO system $(24.2 \mathrm{~kg} \mathrm{DMI} / \mathrm{kg}$ $\mathrm{M}+\mathrm{F}$ ). Meat production ranged from 224 in PT0 to 249 $\mathrm{kg} / \mathrm{ha}$ in PO (Table 1). A greater carrying capacity was associated with greater total GHG emissions (4930 vs. $4270 \mathrm{~kg} \mathrm{CO}$-e/ha for the PO vs. PT2 scenarios, respectively) (Figure 2). Emissions intensity, however, ranged from 15.0 in $\mathrm{PT}+\mathrm{I}$ to $16.2 \mathrm{CO}_{2}-\mathrm{e} / \mathrm{kg} \mathrm{M}+\mathrm{F}$ in $\mathrm{PO}$; relative to $\mathrm{PO}$, the poplar fodder scenario achieved a $10 \%$ reduction in total emissions (Figure 2) and an $8 \%$ reduction in emissions intensity (Table 1).

\section{Discussion}

This desktop study highlights some of the potential outcomes for livestock performance and GHG 
emissions from implementing a pasture-tree vegetation element within a mixed livestock hill country farm system. Important and well-documented effects of spaced trees in reducing pasture production (Douglas et al. 2006b; Guevara-Escobar et al. 2007), increasing reproductive performance (Pollard 2006) and increasing supplementary forage supply (McWilliam et al. 2004; Pitta et al. 2005) were captured in the modelling. However, other potential benefits were not addressed; these benefits could include lesser pasture production declines via soil stabilisation, increased soil carbon sequestration, improved animal performance via reduced heat stress and savings in grazing energy expenditure. Therefore, the full potential of having wide-spaced planted trees in the grazed pasture is not fully accounted for in this analysis.

Because of the intrinsic link between DMI and methane emissions (that accounted for up to $70 \%$ of total GHG emissions), efficiencies in terms of feed conversion (i.e. the amount of dry matter required per unit of $\mathrm{M}+\mathrm{F}$ produced) are critical to the achievement of emission-efficient farms (Grainger \& Beauchemin 2011). These calculations are based on higher pasture utilisation than reported as "average", and hence, greater carrying capacities were achieved relative to the average WLNI system. Notwithstanding these limitations, the comparative aspects of the current modelling exercise identifies farming opportunities to reduce total GHG emissions and emissions intensity from sheep and beef under mixed, pasture-tree farming systems.

The shelter offered by the space-planted trees that was reflected in higher lamb weaning percentages lead to an increase in meat produced per breeding ewe. These outcomes were captured in overall greater ewe efficiencies, reflecting a greater feed energy shift of the PT scenarios towards production rather than maintenance (Table 1). Reproductive rates used in the current modelling exercise were in agreement with those reported by McWilliam et al. (2004) for ewes fed different levels of poplar supplementation. A kinder environment under tree-pasture systems may provide more predictable outcomes (i.e., weaned lambs) and may be less likely to result in large losses of lambs in a storm event (Pollard 2006). Anecdotal evidence suggests that breeding ewes in such environments would be kept for longer, and fewer replacements would be needed.

Management options that reduce the proportion of feed energy expended on animal maintenance and increase the proportion of energy expended on production are often effective in reducing emissions intensity (Grainger \& Beauchemin 2011). The breeding phase often contributes the largest proportion of total GHG emissions from livestock production systems. As the quest for further productivity gains in the sheep and beef sector through on-going advances in fecundity, lamb survival, live weight gain and longevity, and the need to limit GHG emissions, continues, PT systems may offer producers more options. The magnitude of the reductions may seem small on an individual basis, but when adopted on a larger scale, it could provide for a significant contribution to New Zealand's total emissions liability given the high proportion of GHG emissions originating from agriculture.

\section{ACKNOWLEDGEMENTS}

This work was funded by the Ministry for Primary Industries, through the Sustainable Land Management and Adaptation to Climate Change (SLMACC) research programme.

\section{REFERENCES}

Beef + Lamb New Zealand 2013. Farm classes. Available at: http://www.beeflambnz.com/information/onfarm-data-and-industry-production/farm-classes/

Betteridge, K.; Costall, D.; Martin, S.; Reidy, B.; Stead, A.; Millner, I. 2012. Impact of shade trees on Angus cow behaviour and physiology in summer dry hill country: Grazing activity, skin temperature and nutrient transfer issues. In: Advanced Nutrient Management: Gains from the Past - Goals for the Future. In: http://flrc.massey.ac.nz/publications. html. Occasional Report No. 25. Fertilizer and Lime Research Centre, Massey University, Palmerston North, New Zealand. 10 pages.

Douglas, G.B.; Walcroft, A.S.; Hurst, S.E.; Potter, J.F.; Foote, A.G.; Fung, L.E.; Edwards, W.R.N.; Dijssel, C.v.d. 2006a. Interactions between widely spaced young poplars (Populus spp.) and introduced pasture mixtures. Agroforestry Systems 66: 165-178.

Douglas, G.B.; Walcroft, A.S.; Hurst, S.E.; Potter, J.F.; Foote, A.G.; Fung, L.E.; Edwards, W.R.N.; Dijssel, C.v.d. 2006b. Interactions between widely spaced young poplars (Populus spp.) and the understorey environment. Agroforestry Systems 67: 177-186.

Gillingham, A.G. 1973. Influence of physical factors on pasture growth on hill country. Proceedings of the New Zealand Grassland Association 35: 77-85.

Grainger, C.; Beauchemin, K.A. 2011. Can enteric methane emissions from ruminants be lowered without lowering their production? Animal Feed Science and Technology 166-167: 308-320.

Guevara-Escobar, A.; Kemp, P.D.; Mackay, A.D.; Hodgson, J. 2007. Pasture production and composition under poplar in a hill environment in New Zealand. Agroforestry Systems 69: 199-213.

Mackay, A.D.; Rhodes, A.P.; Power, I.; Wedderburn, M.E. 2012. Has the eco-efficiency of sheep and beef farms changed in the last 20 years? Proceedings of the New Zealand Grassland Association 74: 11-16. 
McIvor, I.; Douglas, G.B. 2012. Poplars and willows in hill country - Stabilising soils and storing carbon. In: Advanced Nutrient Management: Gains from the Past - Goals for the Future. http://flrc.massey. ac.nz/publications.html. Occasional Report No. 25. Fertilizer and Lime Research Centre, Massey University, Palmerston North, New Zealand. 11 pages.

McWilliam, E.L.; Barry, T.N.; Lopez-Villalobos, N.; Cameron, P.N.; Kemp, P.D. 2004. The effect of different levels of poplar (Populus) supplementation on the reproductive performance of ewes grazing low quality drought pasture during mating. Animal Feed Science and Technology 115: 1-18.

Ministry for Primary Industries 2012. Farm Monitoring 2012. Western lower North Island intensive sheep and beef. Available at: http://www.mpi.govt.nz/newsand-resources/statistics-and-forecasting/agriculture/ pastoral-monitoring/
Ministry for Primary Industries 2014. Situation and outlook for primary industries 2014. Mid-year update, December 2014. Available at: http://www. mpi.govt.nz/exporting/

Pitta, D.W.; Barry, T.N.; Lopez-Villalobos, N.; Kemp, P.D. 2005. Effects on ewe reproduction of grazing willow fodder blocks during drought. Animal Feed Science and Technology 120: 217-234.

Pollard, J.C. 2006. Shelter for lambing sheep in New Zealand: a review. New Zealand Journal of Agricultural Research 49: 395-404.

Wheeler, D.M.; Ledgard, S.F.; DeKlein, C.A.M. 2008. Using the OVERSEER nutrient budget model to estimate on-farm greenhouse gas emissions. Australian Journal of Experimental Agriculture 48: 99-103. 
